\title{
Sesame (Sesamum indicum L.) Yield and Yield Components Influenced by Nitrogen and Foliar Micronutrient Applications in the Fayoum Region, Egypt
}

\author{
A. M. A. El-Sherif \\ Agronomy Department, Faculty of Agriculture, Fayoum \\ University, Fayoum, Egypt.
}

\begin{abstract}
THIS STUDY investigates nitrogen and foliar micronutrient applications to Sesame (Sesamum indicum L.) and their influence on yield and selected yield components. Also, determining the variation of contributions traits with seed yield of Sohag1 sesame variety under studied treatments in newly reclaimed soil condition. The experiment was conducted in split-plot design with three replications during the 2013 and 2014 growing summer seasons with four nitrogen rates as the main treatment and three rates of foliar micronutrients as sub plots. Results indicated that significant $\mathrm{N}$ levels and application of mixture of foliar micronutrients treatments for all studied traits in both seasons. The higher nitrogen rate $80 \mathrm{~kg} \mathrm{fad}^{-1}$ (fad. $=0.42 \mathrm{ha}$ ) gave the highest averages for most traits except oil percentage was decreased in higher $\mathrm{N}$ level rate. Also, application of $400 \mathrm{~g} /$ fad foliar micronutrients led to increase for all studies traits, and the interaction between $80 \mathrm{~kg} \mathrm{~N} / \mathrm{fad}$ with $400 \mathrm{~g} / \mathrm{fad}$ foliar microelement gave the highest means for all studies traits in both seasons except harvest index was $60 \mathrm{~kg} \mathrm{fad}^{-1}$ with $400 \mathrm{~g} / \mathrm{fad}$ in the $1^{\text {st }}$ season and $40 \mathrm{~kg} \mathrm{fad}^{-1}$ with $400 \mathrm{~g} / \mathrm{fad}$ in $2^{\text {nd }}$ season. On the other hand, the highest value of oil percentage was recorded due to the interaction between $20 \mathrm{~kg} \mathrm{~N} / \mathrm{fad}$ and $400 \mathrm{~g} / \mathrm{fad}$ foliar micronutrients. According, the path way analysis of different traits contribute to seed yield per faddan show that the plant height followed by seed yield/plant and harvest index exhibited high positive direct effects, while the number of capsules /plant through weight of capsules and through seed yield /plant followed by seed yield /plant through weight of capsules /plant exhibited high positive the indirect effect.
\end{abstract}

Keywords: Sesame, Nitrogen fertilization, Foliar spraying , Land reclamation , Yield and yield components, Path coefficient analysis.

Sesame (Sesamum indicum L.) could be considered as one of the major ancient and important oil crops in the world. The crop has high quality of edible oil (42$54 \%$ ) and protein contents ( 22 to $25 \%$ ). It is an important oil seed crop of the warm region of the tropics and sub-tropics. The largest producers of the crop in 2007 were India, China, Myanmar, Sudan, Ethiopia, Uganda and Nigeria. The sesame cultivated area all over the world in 2013 was 9416368.86 ha. (FAO, 2015). In Egypt, sesame is considering essentials oilseed crop, because most of its seeds are directly consumed. The sesame production area in Egypt has 
decreased from 41214 faddan, in 2011 to 24639 faddan, in 2013 while, the productivity increased from $578 \mathrm{~kg} \mathrm{fad}^{-1}$ in 2011 to $586 \mathrm{~kg} \mathrm{fad}^{-1}$ in 2013 (Bulletin Agricultural Statistics, 2013 and 2014). The planting of sesame in less fertile soils and absence of nutrient management is one of the major causes for Low cultivated area and production (Purushottam, 2005).

Due to the increase in the demand for oils sources as well as the shortage of our local production, the expansion of oil crops cultivation in newly reclaimed lands would be quite helpful to cover the country needs. Sesame crop could be considered as a good choice to increase the local edible oil production by increasing growing area and raising the yield per unit area in newly reclaimed land, because of its short duration (3-4 months), low water requirement and drought resistance (Bedigian \& Harlan, 1986).

The growing environment and cultural practices effect on yield of sesame. Nitrogen is a component of amino acids, proteins, chlorophyll, nucleic acids, ATP, and phospholipids influences respiration, photosynthesis, cellulose synthesis, root growth, maturity, nodulation and seed. The $\mathrm{N}$ fertilizer is considered one of the most important factors to increase crop yields per unit area. $\mathrm{N}$ application to sesame has been reported to increase plant height, number of capsules /plant, seed index, and yield of seed, (El-Habbasha et al., 2007; ElNakhlawy \& Shaheen, 2009; Shehu et al., 2010; Noorka et al., 2011; Boghdady et al., 2012; Jouyban \& Moosavi, 2012 and Blal et al., 2013 ). On the other side, seed oil content was reduced by increasing $\mathrm{N}$ application (El-Habbasha et al., 2007 and Noorka et al., 2011). While, Boghdady et al. (2012) specified that the treatment of $100 \%$ from the suggested dosage of mineral fertilizers NP did not factually contrast from that of half of the prescribed dosage of NP in addition to biofertilizers in their effect. Blal et al. (2013) found that increasing $\mathrm{N}$ fertilization up to $40 \mathrm{~kg} / \mathrm{fad}$ plus seryalin significantly increased 1000 -seed weight, number of capsules plant ${ }^{-1}$, capsules weight, seed yield plant ${ }^{-1}$ and oil $\%$. However, increasing $\mathrm{N}$ application to $60 \mathrm{~kg} / \mathrm{fad}$ plus seryalin reduced all these traits. Also, Eisa et al. (2010) showed that micronutrients (Fe, Zn, Mn) as foliar spray on sesame improved their growth and yields. Yadav et al., (2009) noted that utilization of either zinc or iron alone or in blend with natural manures has brought about increased all the development and yield of sesame. Heidari et al. (2011) found that iron fertilizer had significant effect on sesame seed yield. Hamideldin \& Hussein (2014) showed that spraying sesame plants with boron (B) solutions improved their growth and yields. path way analysis is necessary to split the simple correlation into direct and indirect effects (Dewey \& Lu, 1959). This would help to identify with certainty the component traits to be relied upon during selection to improve seed yield.

The objectives of the present investigations were: (i) to study the effect of nitrogen fertilization, mixture of foliar microelements and their interactions on yield and other studied traits and (ii) to determine characters of the strongest association and contribution with seed yield of sesame under studied treatments in newly reclaimed soil condition.

Egypt. J. Agron. Vol. 38, No. 3 (2016) 


\section{Materials and Methods}

Two field experiments were carried out at the experimental farm of the Faculty of Agriculture, Demo, Fayoum University. It aimed to study the effect of nitrogen fertilizer and mixture of foliar micronutrients rates on yield, its components and oil percentage and determine suitable criteria for yield improvement of Sohag 1 sesame variety under sandy loam soil. Four nitrogen fertilizer rate i.e., $(\mathrm{N} 1)=20,(\mathrm{~N} 2)=40,(\mathrm{~N} 3)=60$ and $(\mathrm{N} 4)=80 \mathrm{~kg} \mathrm{fad}^{-1}(\mathrm{fad}=$ $0.42 \mathrm{ha})$ as ammonium nitrate $33.5 \% \mathrm{~N}$ in two equal doses at $2^{\text {nd }}$ and $3^{\text {rd }}$ irrigation. And three mixtures with foliar microelement rates, i.e., $(\mathrm{M} 1)=200$, $(\mathrm{M} 2)=300$ and $(\mathrm{M} 3)=400 \mathrm{~g} \mathrm{fad}^{-1}\left(\right.$ dissolved in $200 \mathrm{~L}$ water fad $\left.{ }^{-1}\right)$ were applied. The micronutrients were added in form of EDTA (Fe 7.5\%, Mn 3.5\%, Zn $0.70 \%$, $\mathrm{Cu} 0.28 \%, \mathrm{~B} 0.65 \%$ and Mo $0.30 \% \mathrm{w} / \mathrm{w})$ in three equal doses at the $1^{\text {st }}, 2^{\text {nd }}$ and $3^{\text {rd }}$ irrigations .

A split-plot design with randomized complete block arrangement was used with three replications in both seasons. The four nitrogen treatments were allotted to the main plots and mixture of foliar microelements treatments were devoted to sub-plots. The sub-plots area was $10.5 \mathrm{~m}^{2}$ ( $3 \times 3.5 \mathrm{~m}$ equal $\left.1 / 400 \mathrm{fad}\right)$ consisted of five rows. The variety was obtained from the Oil Crops Research Section, Field Crop Research Institute, ARC, Giza, Egypt. Sesame seeds (Sohag1) at the rate of $4 \mathrm{~kg} \mathrm{fad}^{-1}$. Seeds were planting at hills $10 \mathrm{~cm}$ apart. At the $1^{\text {st }}$ irrigation, the plants were thinned to be one plants hill ${ }^{-1}$. Calcium super phosphate $\left(15.5 \% \mathrm{P}_{2} \mathrm{O}_{5}\right)$ at rate of $200 \mathrm{~kg} \mathrm{fad}^{-1}$ was added during soil preparation and $50 \mathrm{~kg} \mathrm{fad}^{-1}$ potassium sulphate $\left(48 \% \mathrm{~K}_{2} \mathrm{O}\right)$ with the $2^{\text {nd }}$ irrigation were added, all other recommended agricultural practices for sesame production. Soil physical and chemical properties of the experimental site were determined according to Wilde et al. (1985) and presented in Table 1.

At harvesting, random sample of five guarded plants was taken from each sub-plot to determine the traits; plant height $(\mathrm{cm})$, stem diameter $(\mathrm{cm})$, number of capsules plant ${ }^{-1}$, weight of capsules plant ${ }^{-1}(\mathrm{~g})$, and seed yield plant ${ }^{-1}(\mathrm{~g})$. Seed index, grain yield in $\mathrm{kg}$ was weighed from the whole area of each experimental unit (sub-plot) and harvest index. In addition, seed oil content (\%) that determined by using Soxhelt extraction apparatus using petroleum either as a solvent according to A.O.A.C (1990).

All obtained data were statistically analyzed according to the technique of analysis of variance (ANOVA) for the split- plot design according to Gomez \& Gomez (1984). Least Significant Difference (LSD) method was used to test the differences between treatment means at $5 \%$ level of probability. Path coefficient analysis partitions correlation coefficients into direct and indirect effects through alternate pathways. Path coefficient analysis was done following to the method suggested by Dewey \& Lu (1959). The direct and indirect effects were classified based on scale given by Lenka \& Mishra (1973) (Table 2). 
TABLE 1. Physical and chemical properties of the experimental soil in the two growing summer seasons 2013 and 2014.

\begin{tabular}{|c|c|c|c|}
\hline \multicolumn{2}{|l|}{ Properties } & 2013 & 2014 \\
\hline \multicolumn{4}{|l|}{ Physical properties: } \\
\hline \multicolumn{2}{|l|}{ Sand \% } & 75.64 & 76.46 \\
\hline \multicolumn{2}{|l|}{ Silt \% } & 12.43 & 11.87 \\
\hline \multicolumn{2}{|l|}{ Clay \% } & 11.93 & 11.67 \\
\hline \multicolumn{2}{|c|}{ Texture class } & Loamy sand & Loamy sand \\
\hline \multicolumn{4}{|c|}{ Chemical properties: } \\
\hline \multicolumn{2}{|c|}{$\mathrm{CaCO3 \%}$} & 10.11 & 8.64 \\
\hline \multicolumn{2}{|c|}{ Ece $\mathrm{dS} \mathrm{m}^{-1}$} & 3.56 & 3.64 \\
\hline \multicolumn{2}{|l|}{$\mathrm{pH}$} & 7.34 & 7.52 \\
\hline \multicolumn{2}{|l|}{ Organic matter \% } & 0.83 & 0.76 \\
\hline \multicolumn{2}{|c|}{ Total N $\quad(\%)$} & 0.078 & 0.071 \\
\hline \multicolumn{2}{|c|}{ Available $\mathrm{P} \quad(\mathrm{ppm})$} & 6.54 & 5.86 \\
\hline \multicolumn{2}{|c|}{ Available K (ppm) } & 146 & 143 \\
\hline \multirow{4}{*}{$\begin{array}{l}\text { Micronutrients } \\
\quad(\mathbf{p p m})\end{array}$} & $\mathbf{F e}$ & 10.51 & 9.47 \\
\hline & Mn & 2.11 & 1.76 \\
\hline & $\mathbf{C u}$ & 0.52 & 0.24 \\
\hline & Zn & 0.54 & 0.38 \\
\hline
\end{tabular}

TABLE 2. A scale of the direct and indirect effects values and their rate of scale.

\begin{tabular}{|l|c|}
\hline Values of direct and indirect effects & Rate of scale \\
\hline $0.00-0.09$ & Negligible \\
\hline $0.10-0.19$ & Low \\
\hline $0.20-0.29$ & Moderate \\
\hline $0.30-0.99$ & High \\
\hline More than & Very high \\
\hline
\end{tabular}

\section{Results and Discussion}

\section{Effect of nitrogen fertilizer treatments}

Results in Table 3 showed that highly significant differences existed among all $\mathrm{N}$ treatments for all studies traits in both seasons. Applying of the higher nitrogen rate $80 \mathrm{~kg} \mathrm{fad}^{-1}$ gave the highest averages of plant height, No. of capsules per plant, weight of capsules per plant and seed yield/plant in both seasons and seed yield / fad in the first season. While the third level (N3) $60 \mathrm{~kg}$ $\mathrm{N} /$ fad gave the highest averages of seed index in both season, seed yield $\mathrm{kg} \mathrm{fad}^{-1}$ and harvest index in the second season. Concerning, oil (\%) increased with low level of nitrogen $(20 \mathrm{~kg} \mathrm{~N} / \mathrm{fad})$ in both seasons. These increments may be due to the role of nitrogen in stimulating amino acid building and growth hormones, which in turn acts positively cell division and enlargement.

Egypt. J. Agron. Vol. 38, No. 3 (2016) 
TABLE 3. Effect of nitrogen fertilization $\left(\mathrm{kg} \mathrm{fad}^{-1}\right)$ on the seed yield/fad $(\mathrm{kg})$ and its components of sesame in two seasons.

\begin{tabular}{|c|c|c|c|c|c|c|c|c|}
\hline \multirow[t]{2}{*}{ Treatments } & $\begin{array}{c}\text { Plant } \\
\text { height } \\
(\mathrm{cm})\end{array}$ & \begin{tabular}{|c} 
No. of \\
capsules/ \\
plant
\end{tabular} & $\begin{array}{c}\text { Weight } \\
\text { of } \\
\text { capsules/ } \\
\text { plant (g) }\end{array}$ & $\begin{array}{l}\text { Seed } \\
\text { yield/ } \\
\text { plant } \\
(\mathrm{g})\end{array}$ & $\begin{array}{c}\text { Seed } \\
\text { index } \\
(\mathrm{g})\end{array}$ & $\begin{array}{c}\text { Seed yield } \\
(\mathrm{kg}) \text { fad }^{-1}\end{array}$ & $\begin{array}{c}\text { Harvest } \\
\text { index }\end{array}$ & $\begin{array}{l}\text { Oil } \\
(\%)\end{array}$ \\
\hline & \multicolumn{8}{|c|}{$2013\left(1^{\text {st }}\right.$ season $)$} \\
\hline $20 \mathrm{~kg} \mathrm{~N} / \mathrm{fad}$ & 143.44 & 48.00 & 23.78 & 12.04 & 3.63 & 489.33 & 21.98 & 52.21 \\
\hline $40 \mathrm{~kg} \mathrm{~N} / \mathrm{fad}$ & 169.00 & 54.56 & 27.31 & 14.05 & 4.21 & 608.92 & 24.46 & 51.07 \\
\hline $60 \mathrm{~kg} \mathrm{~N} / \mathrm{fad}$ & 186.72 & 67.89 & 32.46 & 17.03 & 4.27 & 636.68 & 24.16 & 50.59 \\
\hline $80 \mathrm{~kg} \mathrm{~N} / \mathrm{fad}$ & 187.50 & 69.89 & 33.29 & 18.06 & 4.21 & 661.56 & 23.70 & 50.22 \\
\hline \multirow[t]{2}{*}{$\operatorname{LSD}(5 \%)$} & 6.67 & 1.70 & 0.58 & 1.23 & 0.12 & 8.71 & 0.39 & 0.32 \\
\hline & \multicolumn{8}{|c|}{$2014\left(2^{\text {nd }}\right.$ season $)$} \\
\hline $20 \mathrm{~kg} \mathrm{~N} / \mathrm{fad}$ & 142.01 & 49.83 & 25.59 & 12.60 & 3.54 & 494.01 & 22.33 & 52.24 \\
\hline $40 \mathrm{~kg} \mathrm{~N} / \mathrm{fad}$ & 164.44 & 60.67 & 29.12 & 15.01 & 4.06 & 596.99 & 24.50 & 51.43 \\
\hline $60 \mathrm{~kg} \mathrm{~N} / \mathrm{fad}$ & 181.89 & 65.06 & 31.89 & 18.06 & 4.37 & 651.91 & 24.78 & 50.82 \\
\hline $80 \mathrm{~kg} \mathrm{~N} / \mathrm{fad}$ & 183.39 & 67.61 & 34.32 & 18.67 & 4.19 & 639.35 & 23.08 & 50.12 \\
\hline $\operatorname{LSD}(5 \%)$ & 1.83 & 1.39 & 1.29 & 0.54 & 0.05 & 6.75 & 0.25 & 0.59 \\
\hline
\end{tabular}

Each observation is a mean of three replication, LSD is less significant differences, fad is faddan $=0.42 \mathrm{ha}$.

These results are in harmony with those found by Sharar et al. (2000), ElHabbasha et al. (2007), Shehu et al. (2010), Noorka et al. (2011), Jakusko \& Usman (2013), Amanullah et al. (2014) and Iorlamen et al. (2014).

\section{Effect of mixture of microelements treats}

Results in Table 4 revealed that highly significant differences existed among all application of mixture of foliar microelements treatments for all studied traits in both seasons. Increasing mixture of foliar microelements rate from 200 to 400 $\mathrm{g} \mathrm{fad}^{-1}$ led to increase for all studied traits in both seasons. May be due to the shortage of these nutrients in the newly reclaimed soils.

Such finding can be attributed to the positive role of these nutrients in the metabolic processes that take place inside the plant of sesame and its importance in the formation and multiplying meristem cells and stimulate growth buds and form new branches. The useful impact of micronutrients on the yield traits of sesame may be because of actuation of different enzymes and proficient usage of applied supplements, the degree of seed yield increment under micronutrients might be because of positive and aggregate impact of bringing about higher 
number of capsules per plant, seed yield per plant and seed index. The obtained results are in agreement to those reported by Yadav et al. (2009), Eisa et al. (2010), Heidari et al. (2011), Hamideldin \& Hussein (2014) and Mahdi (2014).

TABLE 4. Effect of Foliar microelements $\left(\mathrm{g} \mathrm{fad}^{-1}\right)$ on the seed yield/fad $(\mathrm{kg})$ and its components of sesame in two seasons.

\begin{tabular}{|c|c|c|c|c|c|c|c|c|}
\hline \multirow[t]{2}{*}{ Treatments } & $\begin{array}{c}\text { Plant } \\
\text { height } \\
(\mathrm{cm})\end{array}$ & $\begin{array}{c}\text { No. of } \\
\text { capsules / } \\
\text { plant }\end{array}$ & $\begin{array}{l}\text { Weight of } \\
\text { capsules/ } \\
\text { plant }(g)\end{array}$ & $\begin{array}{c}\text { Seed } \\
\text { yield/ } \\
\text { plant } \\
(\mathrm{g})\end{array}$ & $\begin{array}{l}\text { Seed } \\
\text { index }\end{array}$ & $\begin{array}{l}\text { Seed yield } \\
\left(\mathrm{kg}^{-} \text {fad }^{-1}\right.\end{array}$ & $\begin{array}{c}\text { Harvest } \\
\text { index }\end{array}$ & Oil (\%) \\
\hline & \multicolumn{8}{|c|}{$2013\left(1^{\text {st }}\right.$ season $)$} \\
\hline $200 \mathrm{~g} \mathrm{fad}^{-1}$ & 155.88 & 43.00 & 20.13 & 10.20 & 3.92 & 515.01 & 22.24 & 48.86 \\
\hline $300 \mathrm{~g} \mathrm{fad}^{-1}$ & 174.12 & 59.62 & 29.44 & 15.28 & 4.05 & 602.54 & 23.96 & 51.81 \\
\hline $400 \mathrm{~g} \mathrm{fad}^{-1}$ & 185.00 & 77.62 & 38.07 & 20.40 & 4.28 & 679.82 & 24.52 & 52.39 \\
\hline \multirow[t]{2}{*}{$\operatorname{LSD}(5 \%)$} & 2.98 & 1.03 & 0.76 & 0.36 & 0.08 & 6.25 & 0.29 & 0.43 \\
\hline & \multicolumn{8}{|c|}{$2014\left(2^{\text {nd }}\right.$ season $)$} \\
\hline $200 \mathrm{~g} \mathrm{fad}^{-1}$ & 150.75 & 44.04 & 22.31 & 11.35 & 3.86 & 513.28 & 22.59 & 50.01 \\
\hline $300 \mathrm{~g} \mathrm{fad}^{-1}$ & 167.83 & 61.29 & 29.65 & 16.30 & 4.04 & 602.99 & 24.00 & 51.39 \\
\hline $400 \mathrm{~g} \mathrm{fad}^{-1}$ & 185.22 & 77.04 & 38.73 & 20.60 & 4.22 & 670.44 & 24.44 & 52.06 \\
\hline $\operatorname{LSD}(5 \%)$ & 1.21 & 1.33 & 0.69 & 0.60 & 0.03 & 4.31 & 0.20 & 0.43 \\
\hline
\end{tabular}

Each observation is a mean of three replication, LSD is less significant differences, fad. is faddan $=0.42 \mathrm{ha}$.

Effect of interaction between treatments

Regarding the interaction effect between nitrogen and foliar spraying with foliar microelement rates, the results clearly showed significant and highly significant differences for all studied traits in both seasons except seed index in the $1^{\text {st }}$ season and oil percentage in $2^{\text {nd }}$ season which was not significant (Table 5).

According to means comparison of interaction between nitrogen and foliar spraying with foliar microelement rates, the results were obtained from $80 \mathrm{~kg} \mathrm{~N}$ /fad with $400 \mathrm{~g} \mathrm{fad}^{-1}$ foliar microelement gave the highest means for all studies traits in both seasons except harvest index was $60 \mathrm{~kg} \mathrm{fad}^{-1}$ with $400 \mathrm{~g} \mathrm{fad}^{-1}$ in the $1^{\text {st }}$ season and $40 \mathrm{~kg} \mathrm{fad}^{-1}$ with $400 \mathrm{~g} \mathrm{fad}^{-1}$ in $2^{\text {nd }}$ season. On the other hand, the highest value of oil percentage was recorded due to the interaction between $20 \mathrm{~kg} \mathrm{~N} /$ fad and $400 \mathrm{~g} \mathrm{fad}^{-1}$ foliar microelement in both seasons. It could be recommended that to maximize sesame yields $80 \mathrm{~kg} \mathrm{~N} /$ fad together with $400 \mathrm{~g}$ $\mathrm{fad}^{-1}$ foliar microelement should be applied.

Egypt. J. Agron. Vol. 38, No. 3 (2016) 
TABLE 5. Effect of nitrogen fertilization $\left(\mathrm{kg} \mathrm{fad}^{-1}\right)$ and foliar microelements $\left(\mathrm{g} \mathrm{fad}^{-1}\right)$ interactions on the seed yield fad $^{-1}(\mathrm{~kg})$ and its components of sesame in two seasons.

\begin{tabular}{|c|c|c|c|c|c|c|c|c|c|}
\hline & 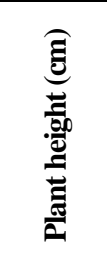 & 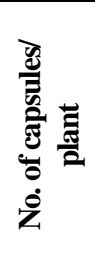 & 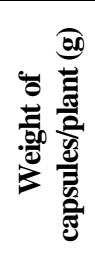 & 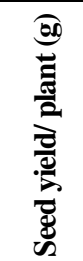 & 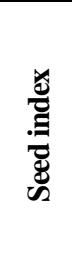 & 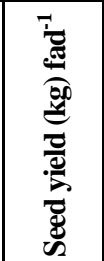 & 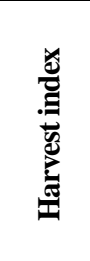 & $\frac{8}{8}$ \\
\hline & & \multicolumn{8}{|c|}{$2013\left(1^{\text {st }}\right.$ season $)$} \\
\hline \multirow{3}{*}{$\begin{array}{c}20 \mathrm{~kg} \\
\mathrm{~N} / \mathrm{fad} \\
(\mathrm{N} 1)\end{array}$} & $200 \mathrm{~g} \mathrm{fad}^{-1}$ & 130.83 & 36.00 & 16.92 & 9.38 & 3.50 & 441.07 & 21.29 & 50.90 \\
\hline & $300 \mathrm{~g} \mathrm{fad}^{-1}$ & 143.67 & 47.00 & 23.42 & 11.93 & 3.57 & 472.34 & 21.88 & 52.48 \\
\hline & $400 \mathrm{~g} \mathrm{fad}^{-1}$ & 155.83 & 61.00 & 31.00 & 14.80 & 3.83 & 554.58 & 22.76 & 53.26 \\
\hline \multirow{3}{*}{$\begin{array}{c}40 \mathrm{~kg} \\
\mathrm{~N} / \mathrm{fad} \\
(\mathrm{N} 2)\end{array}$} & $200 \mathrm{~g} \mathrm{fad}^{-1}$ & 148.33 & 42.00 & 20.07 & 10.43 & 4.09 & 528.18 & 23.25 & 48.14 \\
\hline & $300 \mathrm{~g} \mathrm{fad}^{-1}$ & 172.00 & 51.67 & 26.62 & 13.48 & 4.16 & 615.03 & 25.05 & 52.30 \\
\hline & $400 \mathrm{~g} \mathrm{fad}^{-1}$ & 186.67 & 70.00 & 35.23 & 18.23 & 4.38 & 683.55 & 25.09 & 52.77 \\
\hline \multirow{3}{*}{$\begin{array}{l}60 \mathrm{~kg} \\
\mathrm{~N} / \mathrm{fad} \\
(\mathrm{N} 3)\end{array}$} & $200 \mathrm{~g} \mathrm{fad}^{-1}$ & 172.67 & 43.50 & 20.11 & 10.57 & 4.04 & 524.94 & 21.75 & 48.12 \\
\hline & $300 \mathrm{~g} \mathrm{fad}^{-1}$ & 189.17 & 71.67 & 35.68 & 17.52 & 4.28 & 643.76 & 24.64 & 51.23 \\
\hline & $400 \mathrm{~g} \mathrm{fad}^{-1}$ & 198.33 & 88.50 & 41.60 & 23.00 & 4.49 & 741.34 & 26.10 & 52.41 \\
\hline \multirow{3}{*}{$\begin{array}{l}80 \mathrm{~kg} \\
\mathrm{~N} / \mathrm{fad} \\
(\mathrm{N} 4)\end{array}$} & $200 \mathrm{~g} \mathrm{fad}^{-1}$ & 171.67 & 50.50 & 23.40 & 10.40 & 4.05 & 565.85 & 22.66 & 48.30 \\
\hline & $300 \mathrm{~g} \mathrm{fad}^{-1}$ & 191.67 & 68.17 & 32.04 & 18.18 & 4.19 & 679.03 & 24.28 & 51.24 \\
\hline & $400 \mathrm{~g} \mathrm{fad}^{-1}$ & 199.17 & 91.00 & 44.44 & 25.58 & 4.40 & 739.82 & 24.15 & 51.13 \\
\hline \multirow{2}{*}{\multicolumn{2}{|c|}{$\operatorname{LSD}(5 \%)$}} & 5.95 & 2.07 & 1.52 & 0.72 & NS & 12.50 & 0.58 & 0.86 \\
\hline & & \multicolumn{8}{|c|}{$2014\left(2^{\text {nd }}\right.$ season $)$} \\
\hline \multirow{3}{*}{$\begin{array}{c}20 \mathrm{~kg} \\
\mathrm{~N} / \mathrm{fad} \\
(\mathrm{N} 1)\end{array}$} & $200 \mathrm{~g} \mathrm{fad}^{-1}$ & 127.17 & 35.50 & 19.71 & 10.45 & 3.29 & 454.37 & 22.95 & 51.24 \\
\hline & $300 \mathrm{~g} \mathrm{fad}^{-1}$ & 135.50 & 53.33 & 25.60 & 12.40 & 3.50 & 485.92 & 22.03 & 52.43 \\
\hline & $400 \mathrm{~g} \mathrm{fad}^{-1}$ & 163.37 & 60.67 & 31.45 & 14.95 & 3.82 & 541.75 & 22.02 & 53.04 \\
\hline \multirow{3}{*}{$\begin{array}{c}40 \mathrm{~kg} \\
\mathrm{~N} / \mathrm{fad} \\
(\mathrm{N} 2)\end{array}$} & $200 \mathrm{~g} \mathrm{fad}^{-1}$ & 143.00 & 45.50 & 20.51 & 10.67 & 3.95 & 500.87 & 22.54 & 50.27 \\
\hline & $300 \mathrm{~g} \mathrm{fad}^{-1}$ & 167.67 & 58.00 & 26.84 & 15.53 & 4.07 & 601.19 & 25.11 & 51.31 \\
\hline & $400 \mathrm{~g} \mathrm{fad}^{-1}$ & 182.67 & 78.50 & 40.01 & 18.82 & 4.15 & 688.90 & 25.86 & 52.73 \\
\hline \multirow{3}{*}{$\begin{array}{c}60 \mathrm{~kg} \\
\mathrm{~N} / \mathrm{fad} \\
(\mathrm{N} 3)\end{array}$} & $200 \mathrm{~g} \mathrm{fad}^{-1}$ & 163.00 & 49.67 & 24.84 & 11.92 & 4.16 & 551.15 & 23.00 & 49.45 \\
\hline & $300 \mathrm{~g} \mathrm{fad}^{-1}$ & 178.83 & 62.83 & 30.49 & 18.13 & 4.41 & 684.44 & 25.70 & 51.31 \\
\hline & $400 \mathrm{~g} \mathrm{fad}^{-1}$ & 203.83 & 82.67 & 40.35 & 24.13 & 4.54 & 720.15 & 25.64 & 51.71 \\
\hline \multirow{3}{*}{$\begin{array}{c}80 \mathrm{~kg} \\
\mathrm{~N} / \mathrm{fad} \\
(\mathrm{N} 4)\end{array}$} & $200 \mathrm{~g} \mathrm{fad}^{-1}$ & 169.83 & 45.50 & 24.17 & 12.38 & 4.05 & 546.71 & 21.87 & 49.08 \\
\hline & $300 \mathrm{~g} \mathrm{fad}^{-1}$ & 189.33 & 71.00 & 35.68 & 19.13 & 4.16 & 640.40 & 23.14 & 50.49 \\
\hline & $400 \mathrm{~g} \mathrm{fad}^{-1}$ & 191.00 & 86.33 & 43.11 & 24.48 & 4.38 & 730.94 & 24.23 & 50.78 \\
\hline \multicolumn{2}{|c|}{$\operatorname{LSD}(5 \%)$} & 2.42 & 2.66 & 1.37 & 1.19 & 0.06 & 8.61 & 0.40 & NS \\
\hline
\end{tabular}

Each observation is a mean of three replication, LSD is less significant differences, fad is faddan $=0.42 \mathrm{ha}$. 
Path way analysis

Estimated direct, indirect and residual effect of eight traits under study are presented in Table 6. According to study have suggested scales for path coefficients by Lenka \& Mishra (1973), the data revealed that the plant height followed by seed yield/plant and harvest index exhibited high positive direct effects in the $1^{\text {st }}$ season $(0.291,0.290$ and 0.284 , respectively), while the weight of capsules/ plant followed by harvest index and seed index reveal high positive direct effects in the $2^{\text {nd }}$ season $(0.313,0.267$ and 0.241 , respectively). However, the estimates were low for number of capsules plant ${ }^{-1}(0.167)$, seed index $(0.111)$ in the $1^{\text {st }}$ season and seed yield per plant $(0.192)$ in the $2^{\text {nd }}$ season, and negligible for plant height $(0.085)$ followed by capsules number plant ${ }^{-1}(0.036)$. While, weight of capsules plant ${ }^{-1}(-0.05)$ in $1^{\text {st }}$ season and oil percentage in both season (-0.031 and -0.068 , respectively) exhibited negative and negligible direct effect on seed yield faddan ${ }^{-1}$. The same results obtained by Muhamman et al. (2010) observed that number of branches and plant height reveal positive direct effect on seed yield per faddan.

TABLE 6. Estimation of direct effects and indirect effects for some studied traits on the seed yield/faddan of sesame in 2013 and 2014 seasons.

\begin{tabular}{|c|c|c|c|c|c|c|}
\hline \multirow[b]{2}{*}{ Traits } & \multicolumn{2}{|c|}{$1^{\text {st }}$ season $(2013)$} & \multicolumn{2}{|c|}{$2^{\text {nd }}$ season $(2014)$} & \multicolumn{2}{|c|}{ Total $\mathbf{r}$} \\
\hline & Values & $\begin{array}{c}\text { Rate of } \\
\text { scale }\end{array}$ & Values & $\begin{array}{c}\text { Rate of } \\
\text { scale }\end{array}$ & 2013 & 2014 \\
\hline \multicolumn{7}{|l|}{ 1- Effect of plant height on seed yield/fad: } \\
\hline Direct effect & 0.291 & Moderate & 0.085 & Negligible & & \\
\hline Indirect effect through No. of & & & & & & \\
\hline capsules/plant & 0.141 & Low & 0.031 & Negligible & & \\
\hline Indirect effect through Weight & & & & & & \\
\hline of capsules/plant & -0.041 & Negligible & 0.267 & Moderate & & \\
\hline Indirect effect through Seed yield/plant & 0.234 & Moderate & 0.168 & Low & & \\
\hline Indirect effect through Seed index & 0.096 & Negligible & 0.217 & Moderate & & \\
\hline Indirect effect through Harvest index & 0.215 & Moderate & 0.163 & Low & & \\
\hline Indirect effect through Oil percentage & -0.004 & Negligible & 0.001 & Negligible & $0.931 * *$ & $0.932 * *$ \\
\hline \multicolumn{7}{|c|}{ 2- Effect of No. of capsules/plant on seed yield/ fad.: } \\
\hline Direct effect & 0.167 & Low & 0.036 & Negligible & & \\
\hline Indirect effect through plant height & 0.246 & Moderate & 0.073 & Negligible & & \\
\hline Indirect effect through Weight of & & & & & & \\
\hline capsules/plant & -0.050 & Negligible & 0.307 & High & & \\
\hline Indirect effect through Seed yield/plant & 0.283 & Moderate & 0.182 & Low & & \\
\hline Indirect effect through Seed index & 0.083 & Negligible & 0.172 & Low & & \\
\hline Indirect effect through Harvest index & 0.212 & Moderate & 0.168 & Low & & \\
\hline Indirect effect through Oil percentage & -0.014 & Negligible & -0.022 & Negligible & $0.928 * *$ & $0.915 * *$ \\
\hline \multicolumn{7}{|c|}{ 3- Effect of weight of capsules/plant on seed yield/fad: } \\
\hline Direct effect & -0.050 & Negligible & 0.313 & High & & \\
\hline Indirect effect through plant height & 0.240 & Moderate & 0.072 & Negligible & & \\
\hline Indirect effect through No. of & & & & & & \\
\hline capsules/plant & 0.165 & Low & 0.035 & Negligible & & \\
\hline Indirect effect through Seed yield/plant & 0.281 & Moderate & 0.180 & Low & & \\
\hline Indirect effect through Seed index & 0.081 & Negligible & 0.161 & Low & & \\
\hline Indirect effect through Harvest index & 0.214 & Moderate & 0.157 & Low & & \\
\hline Indirect effect through Oil percentage & -0.016 & Negligible & -0.022 & Negligible & $0.915 * *$ & $0.896 * *$ \\
\hline
\end{tabular}

Egypt. J. Agron. Vol. 38, No. 3 (2016) 
TABLE 6. Cont.

\begin{tabular}{|c|c|c|c|c|c|c|}
\hline \multirow[b]{2}{*}{ Traits } & \multicolumn{2}{|c|}{$1^{\text {st }}$ season $(2013)$} & \multicolumn{2}{|c|}{$2^{\text {nd }}$ season $(2014)$} & \multicolumn{2}{|c|}{ Total $\mathbf{r}$} \\
\hline & Values & $\begin{array}{c}\text { Rate of } \\
\text { scale } \\
\end{array}$ & Values & \begin{tabular}{|c}
$\begin{array}{c}\text { Rate of } \\
\text { scale }\end{array}$ \\
\end{tabular} & 2013 & 2014 \\
\hline \multicolumn{7}{|c|}{ 4- Effect of seed yield/plant on seed yield/ fad: } \\
\hline Direct effect & 0.290 & Moderate & 0.192 & Low & & \\
\hline Indirect effect through plant height & 0.235 & Moderate & 0.074 & Negligible & & \\
\hline $\begin{array}{l}\text { Indirect effect through No. of } \\
\text { capsules/plant }\end{array}$ & 0.163 & Low & 0.034 & Negligible & & \\
\hline Indirect effect through weight of & & & & & & \\
\hline capsules/plant & -0.049 & Negligible & 0.294 & Moderate & & \\
\hline Indirect effect through Seed index & 0.079 & Negligible & 0.179 & Low & & \\
\hline Indirect effect through Harvest index & 0.206 & Moderate & 0.176 & Low & & \\
\hline Indirect effect through Oil percentage & -0.015 & Negligible & -0.016 & Negligible & $0.910 * *$ & $0.933 * *$ \\
\hline
\end{tabular}

5- Effect of seed index on seed yield/fad

Direct effect

Indirect effect through plant height

Indirect effect through No. of

capsules/plant

Indirect effect through weight of

capsules/plant

\begin{tabular}{|c|c|c|c|c|c|}
0.111 & Low & 0.241 & Moderate & & \\
0.251 & Moderate & 0.076 & Negligible & & \\
& & & & \\
0.125 & Low & 0.026 & Negligible & & \\
& & & & & \\
-0.036 & Negligible & 0.209 & Moderate & & \\
0.206 & Moderate & 0.143 & Low & & \\
0.233 & Moderate & 0.170 & Low & & \\
-0.001 & Negligible & 0.013 & Negligible & $0.888^{* * *}$ & $0.877 * *$ \\
\hline
\end{tabular}

Indirect effect through Seed yield /plan

Indirect effect through Harvest index

6- Effect of harvest index on seed yield/fad

Direct effect

Indirect effect through plant height

Indirect effect through No. of

capsules/plant

Indirect effect through weight of

capsules/plant

Indirect effect through Seed yield /plant

Indirect effect through seed index

\begin{tabular}{|c|c|c|c|}
\hline 0.284 & Moderate & 0.267 & Moderate \\
\hline 0.220 & Moderate & 0.052 & Negligible \\
\hline 0.124 & Low & 0.023 & Negligible \\
\hline-0.038 & Negligible & 0.184 & Low \\
\hline 0.210 & Moderate & 0.126 & Low \\
\hline 0.091 & Negligible & 0.153 & Low \\
\hline
\end{tabular}

\begin{tabular}{|l|l|l|l|l|l|l|l} 
Indirect effect through Oil percentage & -0.012 & Negligible & -0.017 & Negligible & $0.880 * *$ & $0.787 * *$ \\
\hline
\end{tabular}

7- Effect of oil percentage on seed yield/fad

Indirect effect through plant height

Indirect effect through No. of

capsules/plant

Indirect effect through weight of

capsules/plant

Indirect effect through Seed yield /plant

Indirect effect through seed index

Indirect effect through harvest index

Residual effect

$*$ and $* *$ is significant at $P \leq 0.05$ and $P \leq 0.01$, respectively. $\mathrm{r}$ is regression

High indirect effect was found for capsules number plant $^{-1}$ via seed yield / plant (0283), through weight of capsule /plant was 0.307 in the $1^{\text {st }}$ season and $2^{\text {nd }}$ season, respectively and followed by seed yield/ plant via weight of capsules/ plant was 0.294 in $2^{\text {nd }}$ season and weight of capsules plant ${ }^{-1}$ via seed yield /plant

Egypt. J. Agron. Vol. 38, No.3 (2016) 
was 0.281 in the $1^{\text {st }}$ season, also followed by seed index through plant height was 0.251 and by oil percentage through seed index was in negative direction $(-0.046)$ in $2^{\text {nd }}$ season and by weight of capsules /plant was -0.025 in the $1^{\text {st }}$ season. The previous results revealed that the indirect effect of number of capsules / plant through weight of capsules and through seed yield /plant followed by seed yield /plant through weight of capsules /plant exhibited high positive indirect effects. The correlation between seed yield /faddan and all studied traits was positive and highly significant except with oil percentage which was not significant. The residual effect $(0.014)$ was low in magnitude which show that the traits under this study were important contributing to seed yield. Similar results recorded by Khan et al. (2001) and Muhamman et al. (2010).

\section{Conclusion}

In generally, using higher level of nitrogen $(80 \mathrm{~kg} \mathrm{~N} / \mathrm{fad})$ and the highest rate of foliar micronutrients (400 g/fad) under newly reclaimed soils produce the heaviest yield of seeds 739.8 and $730.9(\mathrm{t} / \mathrm{fad})$ in $1^{\text {st }}$ and $2^{\text {nd }}$ seasons, respectively. The path way analysis of eight traits contributing towards seed yield per faddan show that the plant height followed by seed yield/plant and harvest index in the $1^{\text {st }}$ season, and the weight of capsules/ plant followed by harvest index and seed index in the $2^{\text {nd }}$ season were exhibited high positive direct effects. However, the indirect effect was high for capsules number/ plant via seed yield /plant, through weight of capsule /plant in the $1^{\text {st }}$ season and $2^{\text {nd }}$ season, respectively.

\section{References}

A.O.A.C. (1990) "Official Methods of Analysis". 15 $5^{\text {th }}$ ed., Association of Official Agricultural Chemists, Washington, D.C., U.S.A.

Amanullah, J. S. A. and Ahmad, M. (2014) Influence of sowing time and nitrogen fertilization on Alternaria leaf blight and oil yield of Sesame cultivars. Pure Appl. Bio., 3(4): 160-166.

Blal, A. E. H., Kamel, S. M. Mahfouz, H. M. and Said, M. (2013) Impact of opened, non opened pollination and nitrogen fertilizer on sesame production in the reclaimed land. Ismailia governorate, Egypt. Cercetări Agronomice în Moldova XLVI (3) ,155.

Boghdady, M. S., Nassar, Rania M.A. and Ahmed, F. A. (2012) Response of sesame plant (Sesamum orientale L.) to treatments with mineral and bio-fertilizers. Res. J. Agric., \& Bio., Sci. 8(2), 127-137.

Bulletin of Agricultural Statistics (2013) Arab Republic of Egypt, Ministry of Agriculture and Land Reclamation, Economic Affairs Sector, summer and nili crops, part (2), p.121.

Bulletin Agricultural Statistics. (2014) Arab Republic of Egypt, Ministry of Agriculture and Land Reclamation, Economic Affairs Sector, summer and nili crops, part (2), p.119

Egypt. J. Agron. Vol. 38, No. 3 (2016) 
Dewey, J. R. and Lu, K. H. (1959) A correlation and path coefficient analysis of components of crested wheat seed production. Agron. J. 51, 515-518.

Eisa, Salwa A. I., Abass, M. M. and Behary, S.S. (2010) Amelioration productivity of sandy soil by using amino acids, sulphur and micronutrients for sesame production. J. American Sci. 6(11), 250257.

El-Habbasha, S.F., Abd El Salam, M.S. and Kabesh, M.O. (2007) Response of two sesame varieties (Sesamum indicum L.) to partial replacement of chemical fertilizers by bio-organic fertilizers. Res. $J$. Agric. Bio. Sci. 3(6), 563-571.

El-Nakhlawy, F. S. and Shaheen, M. A. (2009) Response of seed yield, yield components and oil content to the sesame cultivar and nitrogen fertilizer rate diversity. Env. \& Arid Land Agric. Sci. 20(2), 21-31

FAO (2015) Agricultural data FAOSTAT. Food and Agriculture Organization of the United Nations, Rome.

Gomez, K. A and Gomez, A. A. (1984) "Statistical Procedures for Agriculture Research". $2^{\text {nd }}$ ed. John Wiley and Sons. New York, USA. 680pp.

Hamideldin, N. and Hussein, O. S. (2014) Response of sesame (Sesamum indicum L.) plants to foliar spray with different concentrations of boron. J. Am. Oil Chem. Soc. 91, 1949-1953.

Heidari, M., Galavi, M. and Hassani, M. (2011) Effect of sulfur and iron fertilizers on yield, yield components and nutrient uptake in sesame (Sesamum indicum $L$.) under water stress. African $J$. Biotechnology, 10(44), 8816-8822.

Iorlamen, T., Ayam, F. M. and Akombo, R. A. (2014) Growth and yield response of sesame (Sesamum indicum $L$.) to foliar and soil applied fertilizer in Makurdi, Benue State. International Journal of Scientific Research and Management, 2(2), 528-541.

Jakusko, B.B. and Usman, B.D. (2013) Effects of NPK fertilizer and plant population density on productivity of sesame (Sesamum indicum L). Res. J. Agric. Enviro. Management, 2(5), 121-126.

Jouyban, Z. and Moosavi, S. G. (2012) Effect of different irrigation intervals, nitrogen and superabsorbent levels on chlorophyll index, yield and yield components of sesame. J. Food Agric. Enviro. 10(1), 360-364.

Khan, N. I., Akbar, M. Sabir, K. M. and Iqbal, S. (2001) Characters association and path coefficient analysis in sesame (Sesamum indicum L.). Online J. Bio. Sci. 1(3), 99-100.

Lenka, D. and Mishra, B. (1973) Path coefficient analysis of yield in rice varieties. Indian Journal of Agricultural Sciences, 43, 376-379.

Mahdi, A. S. (2014) Effect of foliar application with iron and zinc on growth and yield of sesame. The Iraqi J. Agric. Sci. 45(1), 18-25.

Muhamman, M. A., Mohammed, S. G., Lado, A. and Belel, M. D. (2010) Interrelationship and path coefficient analysis of some growth and yield characterestics in sesame (Sesamum indicum L.) . Journal of Agricultural Science. 2 (4), 100-105. 
Noorka, I. R., Hafiz, S.I. and El-Bramawy, M. A. S. (2011) Response of sesame to population densities and nitrogen fertilization on newly reclaimed sandy soils. Pakistan J. Bot. 43(4), 1953-1958.

Purushottam, G. (2005) Integrated nutrient management in sesame (Sesamum indicum L.) and its residual effect in succeeding chickpea (Cicer arietinum L.). M.Sc Thesis, University of Agricultural Sciences, Dharwad, India, $100 \mathrm{pp}$.

Sharar, M.S., Ayub, M., Choudhry, M.A. and Asif, M. (2000) Growth and yield of sesame genotypes as influenced by NP application. International J. Agric. Biol. 2(1-2), 86-88.

Shehu, H. E., Kwari, J. D. and Sandabe, M. K. (2010) Nitrogen, phosphorus and potassium nutrition of sesame (Sesamum indicum) in Mubi, Nigeria. New York Sci. J. 3(12), 21-27.

Wilde, S. A., Corey, R. B., Lyer, J. G. and Voigt, G. K. (1985) "Soil and Plant Analysis for Tree Culture". $3^{\text {rd }}$ ed. pp.93-106, Oxford and IBM Publishers, New Delhi, India.

Yadav, R. A., Tripathi, A. K. and Yadav, A. K. (2009) Effect of microelements in combinations with organic manures on production and net returns of sesame (Sesamum indicum) in bundelkhand tract of uttar Pradesh. Ann. Agric. Res. New Series. 30 (1\&2), 53-58.

(Received 3/8/2016; accepted 17/11/2016) 


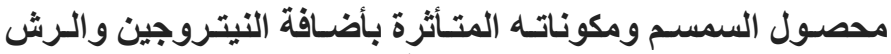 الورقى بالمغذيات الصغرى فى منطقة الفيوم}

$$
\text { قدم المحاصيل محمد الثلية الزيف اعة - جامعة الفيوم - الفيوم - مصر . }
$$

اجري هذا البحث لدراسة تأثير اضافة النتروجين والرش الورقى بالمغذيات

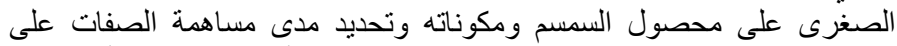

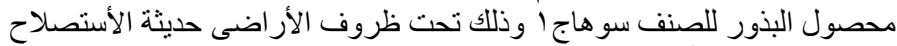

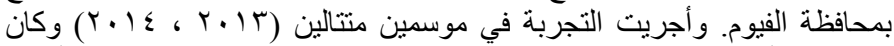

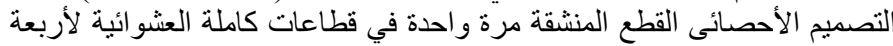

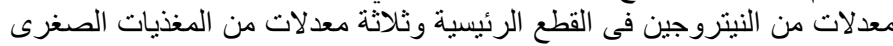

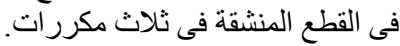

وأثشارت النتائج إلى وجود فروق معنوية للمستويات المختلفة من النتروجين

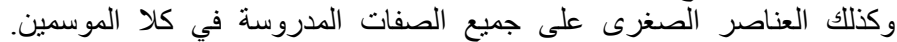

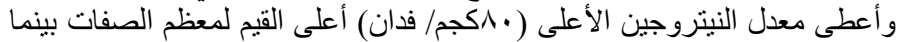

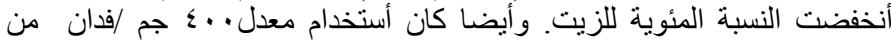

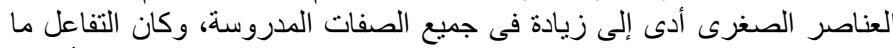

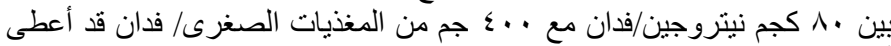

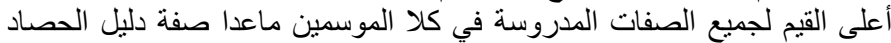

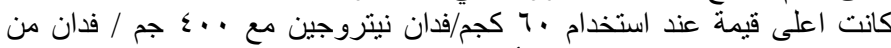

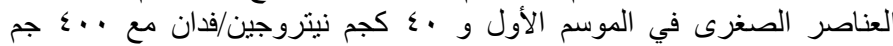

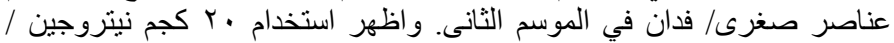

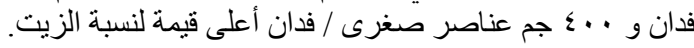

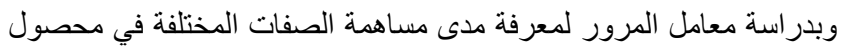

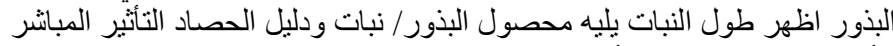

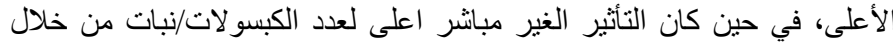

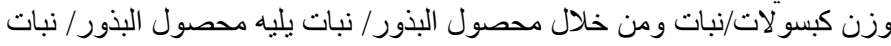
من خلال وزن الكبسولات لات/ نبات خلات 